MUDRA: Journal of Finance and Accounting Volume 4, Issue 1, January-June 2017, pp. 58-69 doi: 10.17492/mudra.v4i01.9779

\title{
Comparative Analysis of Top Private Sector Banks in India based on CAMEL Parameters
}

\section{Rajveer S. Rawlin*, Muddam Mounika**, and Ramaswamy Shanmugam***}

\section{ABSTRACT}

The CAMEL rating is a well-established technique to compare the performance of banks and financial institutions. The Compound Annual Growth Rate (CAGR) is a very useful growth measure. We compare the top five private sector banks in India, ranking them via the CAMEL rating based on the CAGR of CAMEL parameters. Of the banks chosen for the study, IndusInd bank ranked first in capital adequacy, asset quality and earnings quality. HDFC bank ranked first in management efficiency and Axis bank ranked first in liquidity. The bank with the best overall CAMEL rank proved to be IndusInd bank. By providing a basis of comparison for different banks, the CAMEL rating can yield valuable insight to several stake holders of banks such as top management, investors and regulators.

Keywords: CAMEL rating; Banks; Capital adequacy; Asset quality; Management efficiency; Earnings quality; Liquidity.

\subsection{Introduction}

The Indian banking sector has been plagued with the problem of NonPerforming Assets (NPA) for quite some time now. Private banks have seen their stock prices appreciate a lot more than their public counterparts as they have demonstrated much better asset quality in their recent earnings reports. With the recent demonetisation embarked by the government and adoption of international banking norms such as Basel 3 banking margins could come under further pressure.

*Corresponding author; Assistant Professor, Ramaiah Institute of Management, Bangalore, Karnataka, India. (Emailid: rajveer@msrim.org; samuelrr@yahoo.com)

**Graduate student, Ramaiah Institute of Management, Bangalore, Karnataka, India.

(Email id: mounika93m@gmail.com)

*** Visiting Professor, PSG Institute of Management, Coimbatore, Tamil Nadu, India.

(Email id: ramshanmugam@yahoo.co.in ) 
Given the utmost importance of the banking sector to the economy it would prove useful to rate and compare some of India's largest private banks. This study seeks to understand and compare some of India's largest private sector banks via the wellknown CAMEL rating system. The CAMEL rating system is an internationally recognized rating system that regulatory authorities use in order to rate and rank financial institutions according to five factors represented by the acronym "CAMEL". These are Capital Adequacy, Asset Quality, Management, Earnings and Liquidity (CAMEL). Each financial institution is assigned a score based on these measures.An overall ranking based on CAMEL parameters is developed. However the CAMEL model when implemented as it is may not provide a true picture of the bank's performance. Hence using performance measures like the Compound Annual Growth Rate (CAGR) in conjunction with the CAMEL rating parameters will yield more representative results. This can help us compare different banks and financial institutions.

Several studies have illustrated the use of the CAMEL rating as a comparison tool. Sangmi and Nazir (2010) used the Camel rating to study the performance of a few banks in India. Misra and Aspal (2013) compared State Bank of India and its associate banks via the CAMEL rating. Aspal and Malhotra (2013) and Lakhtaria (2013) have studied the financial performance of selected Indian public sector banks through the CAMEL rating model. Kumar et al. (2012) examined the performance of the top twelve highest market capitalized public and private banks in India with the help of CAMEL rating approach.

In our study we focus on the top five private sector banks by market capitalization and attempt to arrive at a ranking methodology for these banks based on the CAMEL approach. We simply don't rank the parameters as they are but rank the banks based on the five year CAGR of each of the CAMEL parameters.

\subsection{Literature Review}

The profitability of a bank often a key measure of performance is predominantly driven by a series of internal and external factors. The internal determinants of bank profitability include but are not limited to bank size, capital, risk management procedures adopted, expenses, and diversification (Molyneux and Thornton, 1992); Goddard et al. (2004); Bodla and Verma, (2006). External determinants of bank profitability include both industry structural determinants such as market concentration, industry size and ownership, and macroeconomic determinants such as inflation, interest rates, money supply and Gross Domestic Product (GDP) (Athanasoglou et al., 2008; Chirwa, 2003). 
Yet another key bench mark of performance is clearly the stock price performance. The stock prices of banks are influenced by several factors. These include but are not limited to changes in bank profitability (Chu and Lim, 1998), bank specific risks (Adenso-Diaz and Gascon, 1997), microeconomic factors such as net asset value per share, dividend percentage, and earnings per share (Uddin, 2009), changes in operating and cost efficiency (Beccalli et al., 2006) and earnings announcements (Seetharaman and Raj, 2011).

The CAMEL rating methodology takes a more holistic view of performance examining it from several vantage points. Sangmi and Nazir, 2010 examined the CAMEL ratings of Punjab national bank and Jammu and Kashmir Bankin India from 2001 to 2005. They found out that both the banks were financially sound as per the CAMEL framework. Misra and Aspal, 2013 compared State Bank of India and its associate banks through the CAMEL rating methodology. He found that State Bank of India had significantly lower CAMEL ratings than its smaller associate banks.

Aspal and Malhotra, 2013 studied the financial performance of selected midsized Indian public sector banks with theCAMEL rating model from 2007 to 2011. They found that bank of Baroda and Andhra bank had the highest CAMEL ratings. Lakhtaria, 2013 studied the top three largest public sector banks namelyState Bank of India (SBI),Bank of Baroda and Punjab National Bank (PNB) using the CAMEL model. He found that the Bank of Baroda had the highest CAMEL rank followed by PNB and SBI.

Kumar et al., 2012 studied the performance of the top 12 Indian private and public banks by market capitalization through the CAMEL rating approach between 2000 and 2011. They found that that private sector banks fared much better than their public counterparts. Jha and Hui, 2012 similarly found that private sector banks outperformed their public counterparts among a cross section of Nepalese commercial banks. Kaur (2010) studied public and private sector banks operating in India via the CAMEL approach over a seven year period from 2001 to 2007. Andhra Bank and State Bank of Patiala ranked as the best public sector bank while Jammu and Kashmir Bank was the best private sector bank.

\subsection{Methodology}

We focus on developing a ranking methodology for a sample of public sector banks based on the five year CAGR of CAMEL parameters. The five CAMEL parameters are as follows: C - Capital Adequacy; A - Asset Quality; M - Management Efficiency; E - Earnings quality; L - Liquidity. 
Capital adequacy is a measure of how adequately capitalised a bank is in its ability to absorb any losses and meeting customer obligations. Two measures of capital adequacy considered in this study are: (i) Capital Adequacy Ratio; and (ii) Debt to Equity Ratio. Asset quality is a measure of the bank's financial health. Improving asset quality is often marked by strong financial performance. Two measures of asset quality considered in this study are: (i) \% Net Non-Performing Assets to Total Advances; and (ii) \% Total Investment to Total Assets. Management efficiency measures how capable top management is in managing its operations and getting the most out of its work force. Two measures of asset quality considered in this study are: (i) Profit per employee; and (ii) Business per employee. Earnings quality looks at how profitable the bank is and its ability to deliver superior returns on its asset base deployed. Two measures of earnings quality considered in this study are: (i) Earnings per share; and (ii) \%Operating Profit to Average Working Funds. Liquidity looks at how well the firm manages and generates its cash to overcome any asset liability mismatches in the near term. Two measures of liquidity considered in this study are: (i) \% Cash to total deposits; and (ii) \% Investment to total deposits

The 5 year CAGR is calculated as:

CAGR $=\left\{[\text { Ending Value/ Beginning Value }]^{1 / 5}-1\right\} \times 100$

The CAGR each of the above parameters is calculated a five year period from the financial year ending March 2012 to financial year ending March 2017. Ranking is done for each of these parameters based on the CAGR obtained. The average rank for each category is determined. An overall CAMEL rank is developed based on average rank of the CAGR's of each of the above parameters and is used to rate the banks. Data on all banks is obtained from the Capitaline database (www.capitaline.com). The following five banks are chosen for the study based on their asset base and market capitalization:

1) HDFC Bank (HDFC)

2) ICICI Bank (ICICI)

3) Kotak Mahindra Bank (Kotak)

4) Axis Bank (Axis)

5) IndusInd Bank (IndusInd)

\subsection{Results}

Table 1 provides the key bank metrics of the selected banks. Table 2 shows the capital adequacy ratio of the five banks studied over the last five years and the five year CAGR of the capital adequacy ratio. IndusInd bank has the highest CAGR of the capital 
62 | MUDRA: Journal of Finance and Accounting, Volume 4, Issue 1, Jan-Jun 2017

adequacy ratio and is ranked 1 . HDFC bank has the lowest CAGR of the capital adequacy ratio and is ranked 5. Table 3 shows the debt to equity ratio of the five banks studied over the last five years and the five year CAGR of the debt to equity ratio. IndusInd bank has the lowest CAGR of the debt to equity ratio and is ranked 1. ICICI bank has the highest CAGR of the debt to equity ratio and is ranked 5. Table 4 shows the $\%$ NPA of the five banks studied over the last five years and the five year CAGR of the $\%$ NPA. IndusInd bank has the lowest CAGR of the \%NPA and is ranked 1. Axis bank has the highest CAGR of the \%NPA and is ranked 5.

Table 1: Some Key Bank Metrics (Billion Rupees)

\begin{tabular}{|l|c|c|c|c|}
\hline \multicolumn{1}{|c|}{ Bank } & Market Cap & Net Interest Income & Net Profit & Total Assets \\
\hline HDFC & 4254 & 693 & 146 & 7088 \\
\hline ICICI & 1860 & 542 & 98 & 7718 \\
\hline Kotak & 1812 & 177 & 34 & 2146 \\
\hline Axis & 1239 & 445 & 37 & 6015 \\
\hline IndusInd & 891 & 144 & 29 & 1401 \\
\hline
\end{tabular}

Source: moneycontrol.com as on 03/07/17

Table 2: Ranking as per the Capital Adequacy Ratio

\begin{tabular}{|c|c|c|c|c|}
\hline Bank/Year & $\mathbf{2 0 1 6 - 1 7}$ & $\mathbf{2 0 1 1 - 1 2}$ & CAGR & Rank \\
\hline HDFC & 16.5 & 14.6 & -2.42 & $\mathbf{5}$ \\
\hline ICICI & 18.52 & 17.39 & -1.25 & $\mathbf{4}$ \\
\hline Kotak & 17.52 & 16.8 & -0.84 & $\mathbf{3}$ \\
\hline Axis & 13.66 & 14.95 & 1.82 & $\mathbf{2}$ \\
\hline IndusInd & 13.85 & 15.31 & 2.02 & $\mathbf{1}$ \\
\hline
\end{tabular}

Source: The Capitaline database

Table 3: Ranking as per the Debt to Equity Ratio

\begin{tabular}{|c|c|c|c|c|}
\hline Bank/Year & $\mathbf{2 0 1 6 - 1 7}$ & $\mathbf{2 0 1 1 - 1 2}$ & CAGR & Rank \\
\hline HDFC & 10.29 & 8.66 & -3.40 & $\mathbf{2}$ \\
\hline ICICI & 6.85 & 6.72 & -0.35 & $\mathbf{5}$ \\
\hline Kotak & 7.23 & 6.77 & -1.30 & $\mathbf{4}$ \\
\hline Axis & 11.52 & 9.79 & -3.21 & $\mathbf{3}$ \\
\hline IndusInd & 11.15 & 7.65 & -7.24 & $\mathbf{1}$ \\
\hline
\end{tabular}

Source: The Capitaline database 
Table 4: Ranking as per the \% Net NPA to Net Advances

\begin{tabular}{|c|c|c|c|c|}
\hline Bank/Year & $\mathbf{2 0 1 6 - 1 7}$ & $\mathbf{2 0 1 1 - 1 2}$ & CAGR & Rank \\
\hline HDFC & 0.2 & 0.33 & 10.53 & $\mathbf{2}$ \\
\hline ICICI & 0.73 & 4.89 & 46.28 & $\mathbf{4}$ \\
\hline Kotak & 0.61 & 1.26 & 15.61 & $\mathbf{3}$ \\
\hline Axis & 0.25 & 2.11 & 53.20 & $\mathbf{5}$ \\
\hline IndusInd & 0.27 & 0.39 & 7.63 & $\mathbf{1}$ \\
\hline
\end{tabular}

Source: The Capitaline database

Table 5 shows the \%total investment to total assets of the five banks studied over the last five years and the five year CAGR of the \%Total investment to Total assets. HDFC bank has the highest CAGR of the \%Total investment to Total assets and is ranked 1. Kotak Mahindra bank has the lowest CAGR of the \% Total investment to Total assets and is ranked 5. Table 6 shows the Profit per employee of the five banks studied over the last five years and the five year CAGR of the Profit per employee. HDFC bank has the highest CAGR of the Profit per employee and is ranked 1. Axis bank has the lowest CAGR of the Profit per employee and is ranked 5.

Table 5: Ranking as per the \% Total Investment to Total Assets

\begin{tabular}{|c|c|c|c|c|}
\hline Bank/Year & $\mathbf{2 0 1 6 - 1 7}$ & $\mathbf{2 0 1 1 - 1 2}$ & CAGR & Rank \\
\hline HDFC & 28.84 & 24.82 & -2.96 & $\mathbf{1}$ \\
\hline ICICI & 32.60 & 20.84 & -8.562 & $\mathbf{4}$ \\
\hline Kotak & 32.84 & 20.99 & -8.564 & $\mathbf{5}$ \\
\hline Axis & 32.62 & 21.41 & -8.08 & $\mathbf{3}$ \\
\hline IndusInd & 25.27 & 20.54 & -4.05 & $\mathbf{2}$ \\
\hline
\end{tabular}

Source: The Capitaline database

Table 6: Ranking as per Profit per Employee (10M Rupees)

\begin{tabular}{|c|c|c|c|c|}
\hline Bank/Year & $\mathbf{2 0 1 6 - 1 7}$ & $\mathbf{2 0 1 1 - 1 2}$ & CAGR & Rank \\
\hline HDFC & 0.08 & 0.16 & 14.86 & $\mathbf{1}$ \\
\hline ICICI & 0.11 & 0.12 & 1.76 & $\mathbf{4}$ \\
\hline Kotak & 0.09 & 0.11 & 4.10 & $\mathbf{2}$ \\
\hline Axis & 0.14 & 0.07 & -12.94 & $\mathbf{5}$ \\
\hline IndusInd & 0.09 & 0.11 & 4.10 & $\mathbf{2}$ \\
\hline
\end{tabular}

Source: The Capitaline database 
Table 7 shows the business per employee of the five banks studied over the last five years and the five year CAGR of the business per employee. HDFC bank has the highest CAGR of business per employee and is ranked 1. Axis bank has the lowest CAGR of business per employee and is ranked 5. Table 8 shows the $\%$ operating profit to average working funds of the five banks studied over the last five years and the five year CAGR of $\%$ operating profit to average working funds. ICICI bank has the highest CAGR of $\%$ operating profit to average working funds and is ranked 1. HDFC bank has the lowest CAGR of $\%$ operating profit to average working funds and is ranked 5.

Table 7: Ranking as per Business per Employee (10M Rupees)

\begin{tabular}{|c|c|c|c|c|}
\hline Bank/Year & $\mathbf{2 0 1 6 - 1 7}$ & $\mathbf{2 0 1 1 - 1 2}$ & CAGR & Rank \\
\hline HDFC & 6.54 & 12.36 & 13.58 & $\mathbf{1}$ \\
\hline ICICI & 7.08 & 9.89 & 6.91 & $\mathbf{2}$ \\
\hline Kotak & 6.13 & 8.35 & 6.38 & $\mathbf{3}$ \\
\hline Axis & 12.76 & 14 & 1.87 & $\mathbf{5}$ \\
\hline IndusInd & 7.88 & 9.16 & 3.06 & $\mathbf{4}$ \\
\hline
\end{tabular}

Table 8: Ranking as per the \%Operating Profit to Average Working Funds

\begin{tabular}{|c|c|c|c|c|}
\hline Bank/Year & $\mathbf{2 0 1 6 - 1 7}$ & $\mathbf{2 0 1 1 - 1 2}$ & CAGR & Rank \\
\hline HDFC & 3.22 & 3.32 & 0.61 & $\mathbf{5}$ \\
\hline ICICI & 2.41 & 3.64 & 8.60 & $\mathbf{1}$ \\
\hline Kotak & 2.79 & 3.03 & 1.66 & $\mathbf{3}$ \\
\hline Axis & 2.94 & 3.11 & 1.13 & $\mathbf{4}$ \\
\hline IndusInd & 2.69 & 3.54 & 5.65 & $\mathbf{2}$ \\
\hline
\end{tabular}

Table 9 shows the earnings per share of the five banks studied over the last five years and the five year CAGR of earnings per share. IndusInd bank has the highest CAGR of earnings per share and is ranked 1. Axis bank has the lowest CAGR of earnings per share and is ranked 5. Table 10 shows the \%cash to total deposits of the five banks studied over the last five years and the five year CAGR \%cash to total deposits. Axis bank has the highest CAGR of \%cash to total deposits and is ranked 1. HDFC bank has the lowest CAGR of \%cash to total deposits and is ranked 5. Table 11 shows the \%investment to total deposits of the five banks studied over the last five years and the five year CAGR \%Investment to total deposits. HDFC bank has the highest CAGR of 
\%investment to total deposits and is ranked 1. Kotak bank has the lowest CAGR of \%investment to total deposits and is ranked 5.

Table 9: Ranking as per Earnings per Share

\begin{tabular}{|c|c|c|c|c|}
\hline Bank/Year & $\mathbf{2 0 1 6 - 1 7}$ & $\mathbf{2 0 1 1 - 1 2}$ & CAGR & Rank \\
\hline HDFC & 21.32 & 56.78 & 21.64 & $\mathbf{2}$ \\
\hline ICICI & 9.85 & 15.29 & 9.19 & $\mathbf{4}$ \\
\hline Kotak & 7.28 & 18.41 & 20.39 & $\mathbf{3}$ \\
\hline Axis & 20.01 & 15.36 & -5.15 & $\mathbf{5}$ \\
\hline IndusInd & 16.8 & 47.95 & 23.34 & $\mathbf{1}$ \\
\hline
\end{tabular}

Source: The Capitaline database

Table 10: Ranking as per the \% Cash to Total Deposits

\begin{tabular}{|c|c|c|c|c|}
\hline Bank/Year & $\mathbf{2 0 1 6 - 1 7}$ & $\mathbf{2 0 1 1 - 1 2}$ & CAGR & Rank \\
\hline HDFC & 8.81 & 5.71 & -8.31 & $\mathbf{5}$ \\
\hline ICICI & 8.6 & 6.45 & -5.59 & $\mathbf{4}$ \\
\hline Kotak & 6.08 & 4.86 & -4.38 & $\mathbf{3}$ \\
\hline Axis & 6.01 & 6.89 & 2.77 & $\mathbf{1}$ \\
\hline IndusInd & 6.99 & 5.59 & -4.37 & $\mathbf{2}$ \\
\hline
\end{tabular}

Source: The Capitaline database

Table 11: Ranking as per the \%Investment to Total Deposits

\begin{tabular}{|c|c|c|c|c|}
\hline Bank/Year & $\mathbf{2 0 1 6 - 1 7}$ & $\mathbf{2 0 1 1 - 1 2}$ & CAGR & Rank \\
\hline HDFC & 36.99 & 34.48 & -1.40 & $\mathbf{1}$ \\
\hline ICICI & 61.16 & 35.32 & -10.40 & $\mathbf{4}$ \\
\hline Kotak & 57.06 & 32.54 & -10.62 & $\mathbf{5}$ \\
\hline Axis & 40.35 & 33.7 & -3.54 & $\mathbf{3}$ \\
\hline IndusInd & 36.65 & 32.22 & -2.54 & $\mathbf{2}$ \\
\hline
\end{tabular}

Table 12 shows the individual segment ranks obtained by taking the average of the ranks of the two ratios that represent each segment and the overall CAMEL rank obtained by taking the average rank of each of the CAMEL segments. IndusInd bank was the best bank in terms of capital adequacy and earnings quality. IndusInd bank also ranked joint first with HDFC bank in asset quality and with Axis bank in liquidity. 
HDFC bank ranked first in management efficiency. IndusInd bank achieved the highest overall CAMEL rank.

Table 12: Individual Segment and Overall CAMEL Rank

\begin{tabular}{|c|c|c|c|c|c|c|}
\hline Bank & C & A & M & E & L & Overall \\
\hline HDFC & 3 & 1 & 1 & 4 & 3 & 2 \\
\hline ICICI & 5 & 3 & 3 & 2 & 4 & 5 \\
\hline Kotak & 3 & 3 & 2 & 3 & 4 & 3 \\
\hline Axis & 2 & 3 & 5 & 5 & 1 & 4 \\
\hline IndusInd & 1 & 1 & 3 & 1 & 1 & 1 \\
\hline
\end{tabular}

\subsection{Discussion and Analysis}

We compare and rank the top five private sector banks by market capitalization in India via the CAMEL rating methodology. While studies on the CAMEL rating tend to focus on an average rank over a period of time we focus on developing a rank based on the CAGR of CAMEL parameters. This approach gives a better measure of performance given the tremendous change in the banking landscape in India over the last few years with reference to asset quality issues and the gradual implementation of Basel III norms by the RBI.

The top five private banks HDFC bank, ICICI bank, Kotak Mahindra bank, Axis bank and IndusInd bank were chosen based on their market capitalization (Table 1). The banks were ranked for the CAGR of each of the CAMEL parameters. The capital adequacy rank (Table 12) was estimated from the average of the ranks from the two sub categories the capital adequacy ratio (Table 2) and the debt to equity ratio (Table 3). IndusInd bank ranked first in capital adequacy while ICICI bank ranked last. Capital adequacy is a very useful metric and in a recent study Zarrouk et al., 2016 found that bank profitability in the Middle East and North Africa (MENA) region was positively affected by the level of capitalization.

The asset quality rank (Table 12) was estimated from the average of the ranks from the two sub categories the \%NPA (Table 4) and the \%total investment to total assets (Table 5). IndusInd bank and HDFC bank ranked joint first in asset quality followed by the other banks. Asset quality often has a direct bearing on profitability. In a recent study that involved U.S. regional banks during the period from 1994 to 2011, Growe et al., (2014) found that provisions for credit losses negatively impact 
profitability. The management efficiency rank (Table 12) was estimated from the average of the ranks from the two sub categories the profit per employee (Table 6) and business per employee (Table 7). HDFC bank ranked first in management efficiency while Axis bank ranked last. Management efficiency is a useful metric to consider in evaluating the efficiency of management and employees and Ben Naceur and Goaied, (2001) found that the best performing Tunisian banks are those that improve labor and capital productivity.

The earnings quality rank (Table 12) was estimated from the average of the ranks from the two sub categories the $\%$ operating income to average working funds (Table 8) and earnings per share (Table 9). IndusInd bank ranked first in earnings quality while Axis bank ranked last. Earnings quality is often an important barometer of stock price performance. Seetharaman and Raj, 2011 found a very strong positive correlation between earnings per share and the share price of a Malaysian bank. The liquidity rank (Table 12) was estimated from the average of the ranks from the two sub categories the $\%$ cash to total deposits (Table 10) and \% investment to total deposits (Table 11). IndusInd bank and Axis bank ranked joint first in liquidity while ICICI bank and Kotak Mahindra bank ranked joint last.

The best overall CAMEL rank was obtained by IndusInd bank which was obtained from the average ranks of each one of the CAMEL parameters. However even IndusInd bank lagged behind in management efficiency. Management at IndusInd bank can focus on this area to strengthen IndusInd bank's position further. The other banks chosen in the study are lagging behind in several of the key CAMEL parameters and management can work on these areas to catch up with the leader IndusInd bank. Investors can look at CAMEL ratings and compare one bank to the other in their efforts to identify the best banks. The use of CAGR in the ranking process makes it more reflective of the banks performance over time.

\subsection{Conclusion}

We develop a ranking methodology based on the CAMEL rating system to compare the top five private sector banks by market capitalization. Out of the five banks chosen for the study IndusInd bank ranked first in capital adequacy and earnings quality. IndusInd bank also ranked joint first in asset quality with HDFC bank and joint first in liquidity with Axis bank. HDFC bank ranked first in management efficiency. The bank with the best overall CAMEL rank proved to be IndusInd bank. The incorporation of CAGR in the ranking process makes the rating more representative of actual performance. The CAMEL rating can serve as a useful measure to compare the 
performance of banks and can provide valuable insight to managers, investors, regulators and other stake holders of banks.

\section{References}

Adenso-Diaz, B. \& Gascon, F. (1997). Linking and weighting efficiency estimates with stock performance in banking firms. Wharton School Working Paper, 97/21.

Aspal, P. K. \& Malhotra, N. (2013). Performance appraisal of Indian public sector banks. World Journal of Social Sciences, 3(3), 71-88.

Athanasoglou, P.P., Brissimis, S.N. \& Delis, M.D. (2008). Bank-specific, industryspecific and macroeconomic determinants of bank profitability. Journal of International Financial Markets, Institutions \& Money, 18(2), 121-136.

Beccalli, E., Casu, B. \& Girardone, C. (2006), Efficiency and stock performance in European banking. Journal of Business Finance and Accounting, 33, 245-262.

Ben Naceur S. \& M. Goaied. (2001). The determinants of the Tunisian deposit banks Performance. Applied Financial Economics, 11, 317-19.

Bodla, B.S. \& Verma, R. (2006). Determinants of profitability of banks in India: A multivariate analysis. Journal of Services Research, 6(2), 75-89.

Chirwa, E. W. (2003). Determinants of commercial banks profitability in Malawi: A co integration approach. Applied Financial Economics, 13(8), 565-571.

Chu, S.F. \& Lim, G.H. (1998). Share performance and profit efficiency of banks in an oligopolistic market: Evidence from Singapore. Journal of Multinational Financial Management, 8, 155-68.

Goddard, J., P. Molyneux, \& Wilson, J.O.S. (2004). The profitability of European banks: A cross-sectional and dynamic panel analysis. Manchester School, 72(3), 363-381.

Growe, G., M. DeBruine , J. Y. L. \& Maldonado, J. F. T. (2014). The profitability and performance measurement of U.S. regional banks using the predictive focus of the fundamental analysis research. Advances in Management Accounting. 24, 189 - 237. 
Jha, S. \& Hui, X. (2012). A comparison of financial performance of commercial banks: A case study of Nepal. African Journal of Business Management, 6(25), 7601-11.

Kaur, H. V. (2010). Analysis of banks in India--A CAMEL approach. Global Business Review, 11(2), 257-280.

Kumar, M. A., Harsha, G. S., Anand, S., \& Dhruva, N. R. (2012). Analyzing soundness in Indian banking: A CAMEL approach. Research Journal of Management Sciences, 1(3), 9-14.

Lakhtaria, N. J. (2013). A comparative study of the selected public sector banks through CAMEL model. Indian Journal of Research, 2(4), 37-38.

Misra, S. K., \& Aspal, P. K. (2013). A CAMEL model analysis of State Bank group. World Journal of Social Sciences, 3(4), 36-55.

Molyneux, P. \& Thornton, J. (1992). Determinants of European bank profitability: A note. Journal of Banking and Finance, 16(6), 1173-1178.

Sangmi, M. D. \& Nazir, T. (2010). Analyzing financial performance of commercial banks in India: Application of CAMEL model. Pakistan Journal of Commerce and Social Sciences, 4 (1): 40-55.

Seetharaman, A. \& Raj, J.R. (2011). An empirical study on the impact of earnings per share on stock prices of a listed bank in Malaysia. International Journal of Applied Economics and Finance, 5(2): 114-126.

Uddin, M.B. (2009). Determinants of market price of stock: A study on bank leasing and insurance companies of Bangladesh. Journal of Modern. Accounting and Auditing. 5(7), $1-7$.

Zarrouk, H., Jedidia, K. B., \& Moualhi, M. (2016). Is Islamic bank profitability driven by same forces as conventional banks? International Journal of Islamic and Middle Eastern Finance and Management, 9(1), 46-66. 